\title{
Determination of Biodiesel Content in Diesel Fuel by Time-Domain Nuclear Magnetic Resonance (TD-NMR) Spectroscopy
}

\author{
Grazielli da Rocha, ${ }^{\dagger}$ Luiz Alberto Colnago, ${ }^{\ddagger}$ Tiago Bueno Moraes, ${ }^{\ddagger}$ Giuliano Fernandes Zagonel, ${ }^{\S}$ \\ Graciela Ines Bolzon de Muniz, ${ }^{\prime}$ Patrício Guillermo Peralta-Zamora, ${ }^{\perp}$ and Andersson Barison ${ }^{*}{ }^{\dagger}+($ ) \\ ${ }^{\dagger}$ NMR Center, Federal University of Paraná (UFPR), Curitiba, PR, Brazil \\ ${ }^{\ddagger}$ Embrapa Instrumentation-Embrapa, São Carlos, SP, Brazil \\ ${ }^{\S}$ Energy Center, Paraná Technology Institute (TECPAR), Curitiba, PR, Brazil \\ "Center of Forest Sciences and Wood, Federal University of Paraná (UFPR), Curitiba, PR, Brazil \\ ${ }^{\perp}$ Department of Chemistry, Federal University of Paraná (UFPR), Curitiba, PR, Brazil
}

Supporting Information

ABSTRACT: Considering the need for knowing the amount of biodiesel in fuels, in order to attend several legislations around the world, this work aimed to develop a new, rapid, and nondestructive time-domain nuclear magnetic resonance (TD-NMR)based method for the biodiesel content determination in diesel-biodiesel blends. Main findings have revealed that both the transverse relaxation time $\left(T_{2}\right)$ and signal areas from relaxation spectra are highly correlated to biodiesel content in the fuel samples. The highest correlation was reached by applying PLS multivariate regression over $T_{2}$ decay curve profiles. Therefore, both univariate and multivariate approaches were able to determine biodiesel content in diesel-biodiesel blends with high accuracy directly from fuel samples in a simple, fast, and inexpensive way.

\section{INTRODUCTION}

Diesel fuel is one of the main petroleum fractions, containing mainly aliphatic hydrocarbons with 30-60 carbons and, in small proportion, aromatic compounds. ${ }^{1}$ Diesel is the most successful fuel worldwide, mainly employed for transportation by truck and ships, as well as, in power generators, because of its high energy density and autoignition properties. ${ }^{2}$ On the other hand, the instability in the petroleum market, the limited availability of crude oil, and, mainly, the severe impact on the environment, including increases in atmospheric $\mathrm{CO}_{2}$ and high emission of pollutants such as sulfur and nitro compounds, have stimulated the search for alternative fuels. ${ }^{3,4}$ In this way, biodiesel is a relevant alternative to replace fossil fuels in the world, since their physicochemical properties are very similar to those of petrodiesel, enabling its use, either neat or blended with petrodiesel, without demanding any modification on diesel engines and existent storage and distribution infrastructure., Biodiesel is essentially composed of fatty acid methyl or ethyl esters obtained through transesterification processes of vegetable oils or animal fats with methanol or ethanol. ${ }^{4,7}$ The addition of biodiesel in fossil fuels presents some important advantages, mostly environmental. This increases the oxygen content (from fatty acids), resulting in a more advanced and faster overall combustion event, which leads less emissions of pollutants, smoke, $\mathrm{SO}_{x}$, and CO.,5,7,9-12 On the other hand, $\mathrm{NO}_{x}$ emissions are increased by using biodiesel. ${ }^{11,12}$ Because of that, blends of biodiesel and petrodiesel have become commercially available all over the world. In the United States, the use of blends containing $20 \%(\mathrm{v} / \mathrm{v})$ biodiesel in petrodiesel (called B20) is usual. ${ }^{13}$ In the European Union (EU), which the largest biodiesel producer in the world, the amount of biodiesel in petrodiesel has gradually increased. The goal is to reach a B20 blend by $2020 .^{14}$ In Brazil, the blends are scheduled to be raised to B10 from the current B7 by 2019. ${ }^{15}$ Therefore, the need has emerged to determine the amount of biodiesel present in petrodiesel. For that purpose, several analytical methods, mostly based on infrared (IR) spectroscopy in combination with multivariate analysis, have been developed, ${ }^{13,16-26}$ which led to the rise of some standard procedures around the world. In this way, several standard testing methods are used to determine the biodiesel content in diesel-biodiesel blends from multiple ranges, for example, ASTM D7371 (1-20\% v/v), EN14078 (0.05-50\% v/v), and NBR $15568(0.5-30 \% v / v) .^{27,28}$

High-resolution nuclear magnetic resonance (NMR) spectroscopy is the most versatile and powerful tool that provides a wide range of information about the system under investigation. NMR spectroscopy has been successfully used in the fuel industry, including petroleum well logging and determination of fuel properties and its chemical composition, as well as in the quality control of final products. ${ }^{29-33} \mathrm{NMR}$ has also been used to determine the research octane number (RON) and motor octane number (MON) in gasoline. ${ }^{34-39}$ The suitable performance of NMR spectroscopy in this area can be justified by the good correlation of NMR data with the physical and chemical properties of fuels. However, such correlations were normally reached only with aid of multivariate analysis. In this way, partial least squares (PLS) analysis has been a very useful tool in exploring NMR data. ${ }^{40-43}$ This approach was used with success to predict the cetane number $(\mathrm{CN})$ on

Received: January 3, 2017

Revised: March 16, 2017

Published: March 28, 2017 
petrodiesel. ${ }^{44-48}$ Regarding the quality control of biodieselpetrodiesel blends, some NMR-based multivariate calibration methods have been developed. The biodiesel content in petrodiesel could be achieved in a simple and fast way, just by acquiring ${ }^{1} \mathrm{H}$ NMR spectra directly from the sample and applying multivariate calibration. ${ }^{49-53}$ The main advantage of using NMR is that the measurements can be acquired directly from the sample, without the need of any laborious, time- and chemical-consuming sample pretreatment. Moreover, modern NMR spectrometers can be fully automated, allowing fast data acquisition and, consequently, the investigation of a large number of samples in a short time. However, high-resolution NMR requires the usage of expensive and sophisticated spectrometers, composed of heavy and bulk high-field superconducting magnets that limit the in situ applications. Thus, NMR is rarely used in the routine analysis when compared to ultraviolet-visible light (UV-Vis) and infrared (IR) techniques.

On the other hand, low-resolution or time-domain nuclear magnetic resonance (TD-NMR) is based on less-expensive, small, and robust benchtop permanent low-field magnets, which significantly reduces the overall system and running costs. Because of the low magnetic field applied, this tool is also called low-field NMR. TD-NMR has been proven to be an excellent alternative to many traditional methods, because of its distinctive characteristics, such as convenience, rapidity, high correlation, reproducibility, preservation of sample integrity, the ability to perform direct measurements without any sample pretreatment, and the possibility for online and in situ application. ${ }^{54-56}$ For these reasons, TD-NMR-based methods have been widely used in industry for many years for qualitative and quantitative analyses. ${ }^{57}$ However, more applications still being discovered, replacing laborious, time- and chemicalconsuming methods, mainly in the analysis of foodstuffs. ${ }^{55,56,58-60}$

In TD-NMR, the analyses are performed mainly by using the differences between the longitudinal relaxation time $\left(T_{1}\right)$ or transverse relaxation time $\left(T_{2}\right)$ (relaxometry) or self-diffusion ( $D$, diffusometry) of the sample components. Indeed, $T_{2}$ values are normally measured instead of $T_{1}$ values. Such choice is based on the time required to obtain the data. To measure the $T_{1}$ values, it is necessary to wait a time period of $5 T_{1}$ between the pulses, which makes the experiment quite long. In contrast, for the acquisition of $T_{2}$ values, this procedure is dispensable. In this way, the Carr-Purcell-Meiboom-Gill (CPMG) is the best spin-echo pulse sequence to measure the transverse relaxation times. The pulse sequence starts with a $90_{x}^{\circ}$ pulse excitation, followed by a train of refocusing $180_{y}^{\circ}$ pulses; in other words, a $90^{\circ}$ phase shift from the excitation pulse, with a delay between the refocusing pulses of $2 \tau$. The phase shift between the first excitation pulse and the train of refocusing pulses was amended in Carr-Purcell pulse sequence ${ }^{61}$ by Meiboom-Gill ${ }^{62}$ in order to avoid cumulative errors due to deviation from the $180^{\circ}$ pulses. Such a change made the CPMG pulse sequence quite robust and insensitive to errors in refocusing pulses.

TD-NMR also has been used as logging sensors in several offline and online analyses in whole fuel industries, and in laboratories to obtain several physical and chemistry properties of fuels, such as oil viscosity, diffusivity, rock porosity, and many others. ${ }^{63-67}$ In addition, TD-NMR, combined with chemometric analysis, has the ability to simultaneously estimate several quality parameters of fuels, such as sulfur content, cetane index, flash point, density, and temperature achieved during distillation to obtain $50 \%$ of distilled (T50) directly in commercial diesel samples. ${ }^{68}$ Regarding the biodiesel industry, TD-NMR (along with the CPMG pulse sequence) has been widely used, mainly in raw-material quality control and for monitoring the transesterification process. In this way, it has been used to determine the oil content and its quality directly from oilseeds, providing important information for the biodiesel production. ${ }^{69,70}$ Similar to that observed in highresolution NMR, most of the TD-NMR-based methods are also followed by multivariate calibration. In this context, the main advantage of chemometric tools is that the analysis can be performed over the entire decay profile and not only in single values such as $T_{1}$ and $T_{2}$ relaxation time, thus avoiding subjectivity when using exponential fitting procedures, which led to improvement in the accuracy.

The goal of this work was to develop a TD-NMR-based multivariate calibration method for determining the biodiesel content in diesel-biodiesel blends through CPMG pulse sequence in a simple and fast way, directly from the fuel. Therefore, adding more TD-NMR applications that could help the improvement of the biofuels industry, from the raw material to the final products.

\section{EXPERIMENTAL SECTION}

Samples. Methyl biodiesel from soybean, palm, and olive oils, as well as ethyl biodiesel from soybean oil samples, were provided by Centro de Energias-TECPAR, while petrodiesel samples containing up to 50 and $500 \mathrm{ppm}$ of sulfur were kindly supplied by UNIBRASPE-Brasileira de Petróleo S.A. All samples were stored at $20{ }^{\circ} \mathrm{C}$ and $30 \%$ humidity, in a climate-controlled room, prior to analysis.

Diesel-biodiesel blends were prepared by mixing each biodiesel sample with petrodiesel in order to cover the full range, from 0 to $100 \%(v / v)$ of biodiesel (B0-B100). Petrodiesel containing biodiesel is designed as $\mathrm{B} x$, where $x$ indicates the volume percentage of biodiesel in the blend. In this light, B2 is a biodiesel-petrodiesel blend containing 2\% $(v / v)$ biodiesel. $^{7}$ Fourteen (14) fuel blends (B0, B2, B4, $\mathrm{B} 6, \mathrm{~B} 8, \mathrm{~B} 10, \mathrm{~B} 15, \mathrm{~B} 20, \mathrm{~B} 30, \mathrm{~B} 40, \mathrm{~B} 50, \mathrm{~B} 60, \mathrm{~B} 80$, and $\mathrm{B} 100$ ) were prepared, in triplicate, for the method development (i.e., for calibration models). A second set of blends (B3, B5, B9, B12, B25, B45, and B70), in duplicate, were used for external validation.

TD-NMR Measurements. TD-NMR measurements were acquired directly from fuel samples on a Bruker Model mq-20 NMR spectrometer, operating at $0.47 \mathrm{~T}$ with a permanent magnet, observing the ${ }^{1} \mathrm{H}$ nucleus at $19.95 \mathrm{MHz}$. The spectrometer was equipped with a single-channel 18-mm-diameter probe, without temperature control. The magnet temperature, including probe, was kept constant at 37.00 $\pm 0.01{ }^{\circ} \mathrm{C} . T_{2}$ decay curves were acquired using a CPMG pulse sequence that consisted of a $90_{x}^{\circ}$ pulse, followed by a train of $180_{y}^{\circ}$ refocusing pulses, separated by an echo time of $500 \mu \mathrm{s}(\tau$ of $250 \mu \mathrm{s}), 4$ scans, $1 \mathrm{~K}$ echoes, and a recycle delay of $10 \mathrm{~s}$. Before TD-NMR analyses, the samples were placed in a thermal box $\left(37.0 \pm 0.5{ }^{\circ} \mathrm{C}\right)$, at least for $30 \mathrm{~min}$, in order to reach the thermal equilibrium with the NMR spectrometer $\left(37.00{ }^{\circ} \mathrm{C}\right)$. Then, $3.0 \mathrm{~mL}$ of fuel was transferred into $18-\mathrm{mm}$ NMR tubes and submitted to TD-NMR analysis. Measurements were performed three times in order to improve accuracy.

Reference Data. The biodiesel contents in diesel fuel were also determined via Fourier transform infrared (FT-IR) spectroscopy, according to Brazilian standard method ABNT NBR 15568:2008. The FT-IR analyses were performed directly from fuel samples on a MIDAC Fox8100 FT-IR spectrometer that was equipped with a fixed volume ZnSe-ATR cell sampling accessory and a DTGS detector. The spectra were recorded at $20.0 \pm 2{ }^{\circ} \mathrm{C}$ over the middle infrared range $\left(4000-650 \mathrm{~cm}^{-1}\right)$ with 36 scans and a spectral resolution of $4 \mathrm{~cm}^{-1}$, with aid of PETRO-QUANT software. Then, $2.0 \mathrm{~mL}$ of fuel were required for each measurement and the background spectra were 
obtained using an empty cell. The biodiesel content was determined with aid of the GRAMS/32 PLSplus/IQ v4.05 software.

Univariate and Multivariate Analysis of TD-NMR Data. First, relaxation data were explored via principal component analysis (PCA) in order to evaluate the reproducibility of the methodology, followed by univariate and multivariate approaches. For univariate analysis, the $T_{2}$ relaxation curves were fitted by biexponential functions available on Origin 9.0 software in order to obtain the $T_{2}$ and coefficient values. Furthermore, the Inverse Laplace Transform (ILT) was applied over the $T_{2}$ decay curves in order to obtain the continuous distribution of $T_{2}$ (i.e., relaxation spectra) and respective signal areas, with aid of an homemade ILT algorithm based on the Tikhonov regularization. ${ }^{72}$ For multivariate analysis, the $T_{2}$ decay curves containing $1 \mathrm{~K}$ data points per sample were investigated using PLS multivariate calibration pattern recognition techniques with the aid of the PLS toolbox in MATLAB software. Prior to PLS analysis, decay curves were normalized and mean-centered, followed by Savitzky-Golay smoothing (3 points, 1 order); preprocessing and normalization (min-max vector) were applied to the NMR dataset. The cross-validation analyses were performed using leave-one-out cross-validation (which is a process in which each sample is predicted by the remaining samples and the procedure is repeated until each sample was been estimated) to determine the optimal number of latent variables (LVs) to be included in each model, to minimize the root-mean-square error of crossvalidation (RMSECV). To develop the prediction models, datasets comprised of the training set $(75 \%)$ and the remaining set $(25 \%)$ was used for validation. The performance of models were evaluated by correlating predict values with those true values, while predictive abilities of the multivariate models were assessed by using an external validation set of blends (see the "Samples" subsection).

\section{RESULTS AND DISCUSSION}

Most of the TD-NMR spectrometers (magnet and probe) operate at warm temperatures in order to stabilize the magnetic field, such as the one used in this work, which operated at 37 ${ }^{\circ} \mathrm{C}$. On the other hand, samples to be investigated normally are found at room temperature. Therefore, initially PCA analyses were performed over $T_{2}$ relaxation curves from some dieselbiodiesel fuel samples at room temperature. These analyses had the intent of evaluating if the samples could be directly inserted into the NMR probe, in order to acquire NMR data, or if it would be necessary to increase the sample temperature to 37 ${ }^{\circ} \mathrm{C}$ prior to NMR analysis. PCA from the $T_{2}$ decay curves obtained from diesel-biodiesel blends samples, including B0 (pure diesel) and B100 (pure biodiesel), showed a systematic dispersion between the replicates for all samples (see Figure S1 in the Supporting Information). This found is probably due to the effects of small changes in sample temperature during the analysis.

The relaxation spectra obtained by the application of ILT over $T_{2}$ decay curves also showed systematic drifts in the spectral profiles of fuel samples when they were sequentially inserted into the magnet (Figure 1). In other words, different $T_{2}$ times were observed when repeating the measurements. On the other hand, when the samples were previously kept at 37 ${ }^{\circ} \mathrm{C}$ inside a thermic box at least for $30 \mathrm{~min}$, no changes between replicates were observed in relaxation spectra (Figure 1). This finding revealed that $T_{2}$ times (i.e., $T_{2}$ decay curves) are greatly affected by small changes in the sample temperature. Therefore, temperature control is essential to avoid misestimation. In this work, all diesel-biodiesel samples were kept at $37{ }^{\circ} \mathrm{C}$ for 30 min prior to TD-NMR measurements.

The $T_{2}$ decay curves, acquired with aid of CPMG pulse sequence, ${ }^{62}$ of biodiesel samples (obtained from methyl and ethyl trans esterification of vegetable oils from different sources, such as soybean, olive, and palm) were quite similar to those of

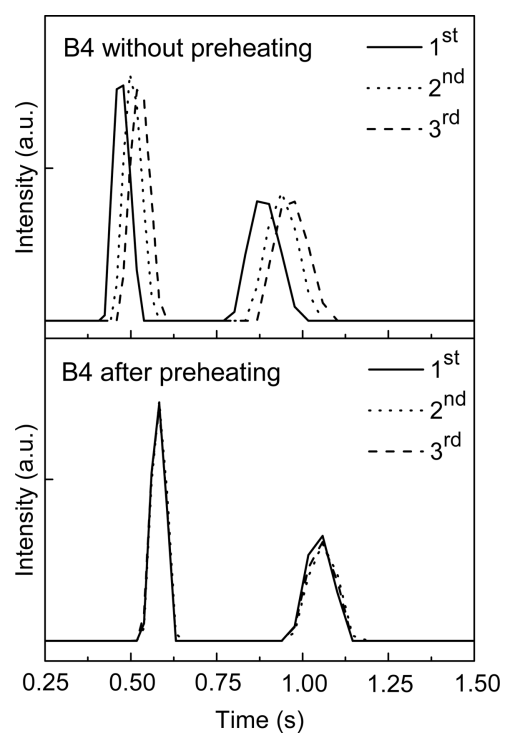

Figure 1. Transverse relaxation $\left(T_{2}\right)$ spectra obtained from B4 dieselbiodiesel blend without and after preheating at $37^{\circ} \mathrm{C}$ for $30 \mathrm{~min}$. The same was observed for all other blends (data not shown).

diesel (see Figure S2 in the Supporting Information). Equally, relaxation spectra from ILT of $T_{2}$ decay curves showed similar spectral profiles (Figure 2). The biodiesel samples presented a

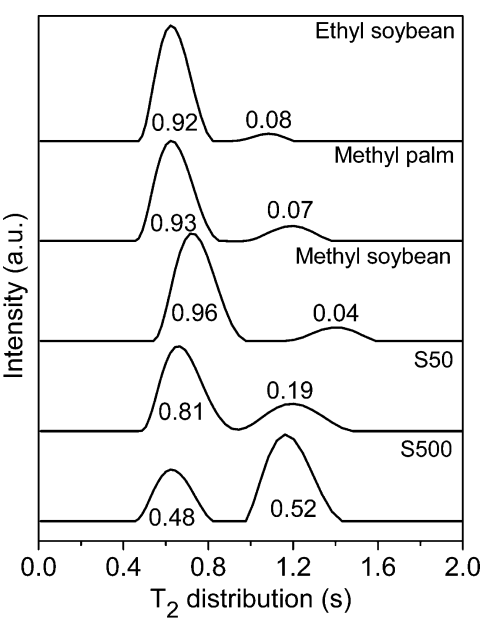

Figure 2. Representative $T_{2}$ relaxation spectra of some biodiesel (ethyl and methyl soybean, and methyl palm) and diesel (S50 and S500, with sulfur limit of 50 and $500 \mathrm{ppm}$, respectively) samples. The numbers given in the graphic represent the relative areas (a.u.).

high intense signal at $\sim 0.6 \mathrm{~s}$ and a small one above $1.1 \mathrm{~s}$. The petrodiesel samples also showed two very similar $T_{2}$ distributions on the relaxation spectra, although the second signal was more intense than those observed for biodiesel (Figure 2). Therefore, according to these findings, one would expect determining the biodiesel content in the dieselbiodiesel blends to be quite difficult.

Univariate Analysis. Although both diesel and biodiesel samples showed very similar $T_{2}$ decay curves (see Figure $S 2$ in the Supporting Information) and $T_{2}$ distribution times in relaxation spectra (Figure 2), it would be expected to signal areas to represent the amounts of biodiesel and diesel. Thus, univariate analyses of diesel-biodiesel blends were performed using $T_{2}$ times and respective coefficients obtained by 
biexponential fitting of the $T_{2}$ decay curves, as well as the respective signal areas from relaxation spectra.

In this light, considering the $T_{2}$ times, a linear correlation between shorter $T_{2}$ components and biodiesel content was achieved (Figure 3), mainly for those blends containing high

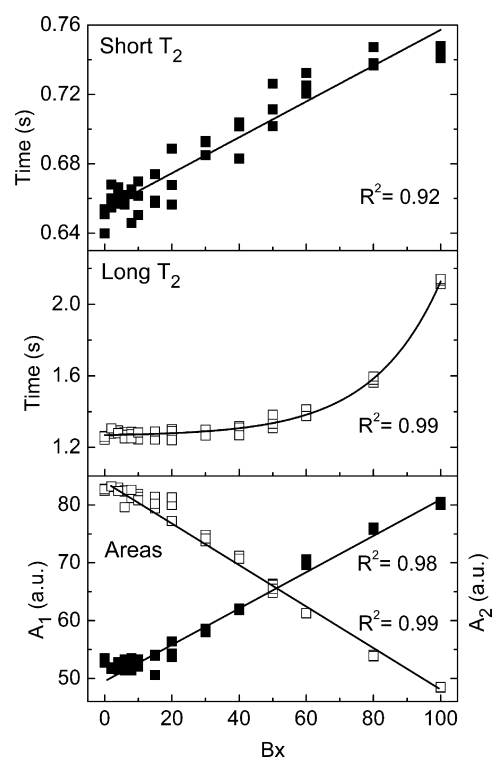

Figure 3. Plots of biodiesel content versus biexponential fitting of $T_{2}$ decay curves and signal areas from relaxation spectra for methyl soybean biodiesel in diesel blends.

biodiesel amounts (i.e., over than B20). However, for those with lower biodiesel contents, a small dispersion of $T_{2}$ times was observed. On the other hand, long $T_{2}$ components showed an exponential correlation with a high degree of correlation $\left(R^{2}\right.$ $=0.99$ ), even for those samples with lower biodiesel content blends (Figure 3). The best correlation was observed when using methyl biodiesel from soybean, which represents most biodiesel plants in Brazil.

Considering the signal area for the shorter $T_{2}$ components in the relaxation spectra, a high degree of correlation $\left(R^{2}=0.98\right)$ and low slope $(S=0.49)$ were found, showing that the signal area was quite sensitive to small changes in biodiesel content (Figure 3). Therefore, the higher the biodiesel content, the higher the signal area of shorter $T_{2}$ components. Similarly, a high degree of correlation $\left(R^{2}=0.99\right)$ was observed between the area from the signal of long $T_{2}$ components and the diesel content, presenting a low slope $(S=0.50)$. Therefore, the higher the diesel content, the higher the signal area of long $T_{2}$ components. In this light, the signal area of the first signal $\left(T_{2}<\right.$ $1 \mathrm{~s})$ in relaxation spectra directly represents the biodiesel content, while the signal area for the second signal $\left(T_{2}>1 \mathrm{~s}\right)$ indicates the amount of petrodiesel (Figure 3 ). The great advantage in using signal areas from relaxation spectra, instead of $T_{2}$ values, is that they are not affected by small changes in signal position, as a consequence of changes in the sample temperature (Figure 1). This finding supports that TD-NMR can be used in a simple way by using $\mathrm{CPMG}^{62}$, which is a robust and well-established pulse sequence, to evaluate the biodiesel content in diesel-biodiesel blends.

Similar results were found by taking into account the coefficients from biexponential fits over $T_{2}$ decay curves (data not shown). However, lower degrees of correlation were observed for those samples with low biodiesel content (i.e.,
$<$ B10). Besides, the validation processes, by using the external validation set of blends, revealed a high prediction error for lower biodiesel content samples. On the other hand, if the expected biodiesel content is $>\mathrm{B} 10$, the calibration curves obtained with $T_{2}$ times, fit coefficient values, or signal areas, can be used to determine the biodiesel content, with reasonable accuracy.

These findings are in agreement with other methods described in the literature for biodiesel content determinations. The ASTM D7371, D7861 and D7467 are used to investigate blends from $\mathrm{B} 1-\mathrm{B} 20, \mathrm{~B} 1-\mathrm{B} 30$ and $\mathrm{B} 6-\mathrm{B} 20$, respectively. While the EN 14078 range $A$ and $B$ are used for blends from $\mathrm{B} 0.05-\mathrm{B} 3$ and $\mathrm{B} 3-\mathrm{B} 20$, respectively. ${ }^{27}$ In summary, univariate analyses are able to determine, with high accuracy, the biodiesel content by means of TD-NMR in diesel-biodiesel blends in a single and fast way for samples with high biodiesel content (>B20).

Multivariate Analysis. Being able to determine the biodiesel content in diesel-biodiesel blends based on univariate data, normally, the use of discrete values has lower predicting power than those performed with multivariate data such as $\mathrm{PLS}^{73}$ once they consider all the information present in $T_{2}$ decay curves and not only a single information. The advantages in using PLS regression, compared to fitting procedures, resides in the fact that it is not necessary to assign the $T_{2}$ values to diesel or biodiesel: neither is biased by the operator and it can be easily automated.

In this light, several PLS models were obtained according to the different sources of vegetable oil and different sulfur contents in diesel. In the attempt to develop a more accurate and robust method, multivariate analysis by PLS regression were performed over entire $T_{2}$ decay curves profile of $\mathrm{B} x$ samples. Since soybean is one of the main sources of vegetable oil and the methyl transesterification is the methodology mostly used for biodiesel production, this system was exhaustively investigated.

PLS regression models showed small RMSECV and high $R^{2}$ values when using $\sim 7$ latent variables (Figure 4 ). When using 4-7 latent variables, no significant reduction was observed in the RMSECV value, although by using 5 latent variables, it was possible to achieve a high percentage of explained variance (99.97\%). This number was adequate to avoid overestimation in the predictions of the constructed models. Thereby, robust multivariate regression models could be achieved (Table 1). Regarding the preprocessing employed, the application of smoothing with a spectral window of three points and the normalization allowed more information to be extracted from the data, yielding in lower RMSECV value and a high $R^{2}$ value. In addition, the data were not autoscaled once the predictive ability of the mean-centered was better for the investigations.

The ability of predicting the biodiesel content in dieselbiodiesel blends was evaluated with external validation sets, in which lower prediction errors were observed, except for those diesel-biodiesel blends with low biodiesel content. The reference method based on FT-IR and multivariate analysis still being more precise than NMR. However, TD-NMR spectrometers can be used in several other applications from raw material to the quality control of final products. ${ }^{63-70}$ Moreover, considering that most legislations around the world use diesel-biodiesel blends of $>$ B10, ${ }^{10,14,15}$ TD-NMR can be an alternative. One great advantage of TD-NMR-based methods is that it can be applied directly to fuel pipelines without the need of sample collecting (i.e., any direct contact with samples). 


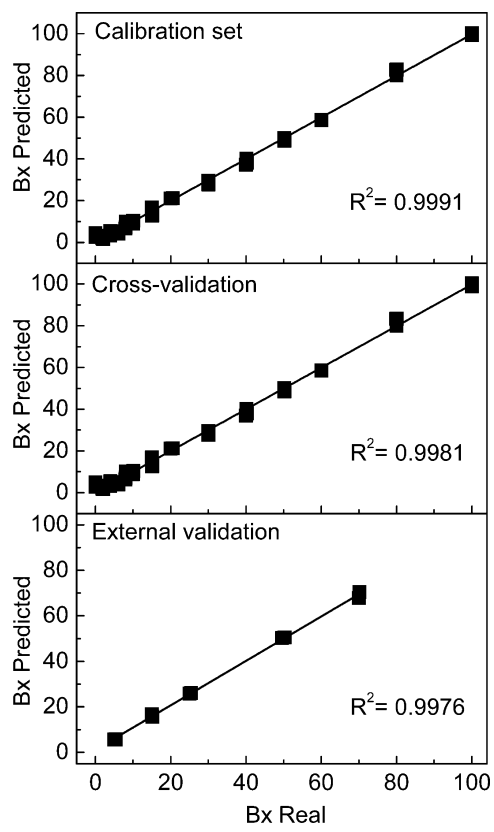

Figure 4. Plot of real biodiesel content versus those predicted by the PLS regression over $T_{2}$ decay curves for methyl soybean biodiesel in diesel blends.

Table 1. Optimization and Validation of Multivariate Models, for Methyl (SM) and Ethyl (SE) Soybean, as Well as Methyl Palm (PM) Biodiesels and Diesel Blends, For Determining $\mathrm{B} x$ Using $T_{2}$ Decay Curves

\begin{tabular}{|c|c|c|c|c|c|}
\hline model & $\begin{array}{l}\text { root-mean- } \\
\text { square error of } \\
\text { cross-validation, } \\
\text { RMSECV }\end{array}$ & $R^{2}$ & $\begin{array}{l}\text { root-mean- } \\
\text { square error } \\
\text { of prediction, } \\
\text { RMSEP }\end{array}$ & $\begin{array}{l}\text { standard } \\
\text { deviation, } \\
\text { SD }\end{array}$ & $\begin{array}{c}\text { mean } \\
\text { relative } \\
\text { error, } \\
\text { MRE } \\
(\%)\end{array}$ \\
\hline $\begin{array}{l}\text { SM/ } \\
\text { S500 }\end{array}$ & 1.08 & 0.999 & 0.48 & 0.55 & 7.53 \\
\hline $\begin{array}{l}\text { SM/ } \\
\text { S50 }\end{array}$ & 2.69 & 0.998 & 0.93 & 1.83 & 11.1 \\
\hline $\begin{array}{l}\text { SE/ } \\
\text { S500 }\end{array}$ & 2.45 & 0.999 & 0.57 & 0.30 & 10.2 \\
\hline $\begin{array}{l}\text { SE/ } \\
\text { S50 }\end{array}$ & 1.71 & 0.994 & 1.04 & 0.53 & 10.2 \\
\hline $\begin{array}{l}\mathrm{PM} / \\
\mathrm{S} 50\end{array}$ & 1.53 & 0.999 & 0.71 & 0.57 & 8.11 \\
\hline
\end{tabular}

Besides, standards and sample derivatization are not required and the equipment requires only a small power supply to work and can be fully automated and operated online.

Therefore, by using PLS regression models over $T_{2}$ decay curves, a high correlation $\left(R^{2}>0.99\right)$ was observed between the predicted biodiesel content and the real ones (Figure 4). These findings show that PLS-based multivariate regression models have good predictive abilities and can be used for determining the biodiesel contents in diesel-biodiesel blends with high accuracy.

Similar results were found by replacing the $T_{2}$ decay curves for the relaxation spectra on PLS multivariate regression models (see Figure S3 in the Supporting Information). However, higher prediction errors (RMSECV) and smaller correlation coefficients $\left(R^{2}\right)$ were achieved.

\section{CONCLUSION}

This work showed that TD-NMR can be used to determine biodiesel content in diesel-biodiesel blends with high accuracy.
The biodiesel content could be assessed in a simple and fast way by acquiring $T_{2}$ decay curves with aid of CPMG pulse sequence directly from the fuel without any sample treatment and plotting data against univariate or multivariate calibration curves. A high correlation was obtained between experimental values and real ones. Therefore, benchtop low-field NMR spectrometers can be a versatile tool for determining biodiesel content, mainly because of its mobility, which permits in situ analysis and the low cost of the equipment. Moreover, low-field or TD-NMR spectrometers can be used in several other key points in diesel and biodiesel plants, from the oil seed to commercial fuel.

\section{ASSOCIATED CONTENT}

\section{Supporting Information}

The Supporting Information is available free of charge on the ACS Publications website at DOI: 10.1021/acs.energyfuels.6b03508.

(PDF)

\section{AUTHOR INFORMATION}

\section{Corresponding Author}

*Tel.: + 55413361 3268. Fax: + 55413361 3186. Address:

NMR Center, Department of Chemistry, UFPR, P.O. Box 19081, 81530-900, Curitiba, Paraná, Brazil. E-mail: andernmr@ ufpr.br.

ORCID $\odot$

Andersson Barison: 0000-0001-9381-8239

Notes

The authors declare no competing financial interest.

\section{ACKNOWLEDGMENTS}

The authors are grateful to CAPES, Finep, CNPq, Fundação Araucária, and UFPR for financial support and fellowships, and UNIBRASPE and TECPAR for providing diesel and biodiesel samples.

\section{REFERENCES}

(1) Morgano, M. A.; Faria, C. G.; Ferrão, M. F.; Ferreira, M. M. C. Quim. Nova 2007, 30, 346-350.

(2) Broge, J. L. Automot. Eng. Int. 2002, 110, 40-49.

(3) Stauffer, E.; Byron, D. J. Forensic Sci. 2007, 52, 371-379.

(4) Knothe, G.; Krahl, J.; Gerpen, J. The Biodiesel Handbook, 2nd Edition; AOCS Press: Champaign, IL, 2005.

(5) Agarwal, A. K. Prog. Energy Combust. Sci. 2007, 33, 233-71.

(6) Tat, M. E.; Van Gerpen, J. H. J. Am. Oil Chem. Soc. 1999, 76, 1511-1513.

(7) Pinto, A. C.; Guarieiro, L. L. N.; Rezende, M. J. C.; Ribeiro, N. M.; Torres, E. A.; Lopes, W. A.; Pereira, P. A. P.; de Andrade, J. B. J. Braz. Chem. Soc. 2005, 16, 1313-1330.

(8) Meher, L. C.; Vidya Sagar, D.; Naik, S. N. Renewable Sustainable Energy Rev. 2006, 10, 248-268.

(9) Encinar, J. M.; González, J. F.; Rodríguez-Reinares, A. Fuel Process. Technol. 2007, 88, 513-522.

(10) Knothe, G. Trans. ASAE 2001, 44, 193-200.

(11) Çelikten, I.; Koca, A.; Ali Arslan, M. Renewable Energy 2010, 35, 814-820.

(12) Hoekman, S. K.; Robbins, C. Fuel Process. Technol. 2012, 96, 237-249.

(13) Knothe, G. J. Am. Oil Chem. Soc. 2001, 78, 1025-1028.

(14) Directive 2003/30/EC of the European Parliament and of the Council of 8 May 2003 on the promotion of the use of biofuels or other renewable fuels for transport. In Official Journal of the European Union, 2003. 
(15) Lei no 13.263 da presidência Republica do Brasil de 23 de Março de 2016 que altera a lei no 13.033 de 24 de Setembro de 2014 para dispor sobre os percentuais de adição de biodiesel ao óleo diesel comercializado no território nacional. In Diário Oficial da União, 2016.

(16) Birova, A.; Svajdlenka, E.; Cvengross, J.; Dostalikova, V. Eur. J. Lipid Sci. Technol. 2002, 104, 271-277.

(17) Oliveira, J. S.; Montalvão, R.; Daher, L.; Suarez, P. A. Z.; Rubim, J. C. Talanta 2006, 69, 1278-1284.

(18) Fernanda Pimentel, M.; Ribeiro, G. M. G. S.; da Cruz, R. S.; Stragevitch, L.; Pacheco Filho, J. G. A.; Teixeira, L. S. G. Microchem. J. 2006, 82, 201-206.

(19) Oliveira, F. C. C.; Brandão, C. R. R.; Ramalho, H. F.; da Costa, L. A. F.; Suarez, P. A. Z.; Rubim, J. C. Anal. Chim. Acta 2007, 587, 194-199.

(20) Aliske, M. A.; Zagonel, G. F.; Costa, B. J.; Veiga, W.; Saul, C. K. Fuel 2007, 86, 1461-1464.

(21) Guarieiro, L. L. N.; Pinto, A. C.; Aguiar, P. F.; Ribeiro, N. M. Quim. Nova 2008, 31, 421-426.

(22) Zawadzki, A.; Shrestha, D. S.; He, B. Trans. ASAE 2007, 50, 1349-1353.

(23) Sastry, G. S. R.; Krishna Murthy, A. S. R.; Prasad, P. R; Bhuvaneswari, K.; Ravi, P. V. Energy Sources, Part A 2006, 28, 13371342.

(24) Corgozinho, C. N. C.; Pasa, V. M. D.; Barbeira, P. J. S. Talanta 2008, 76, 479-484.

(25) Reddy, C. M.; De Mello, J. A.; Carmichael, C. A.; Peacock, E. E.; Xu, L.; Arey, J. S. Environ. Sci. Technol. 2008, 42, 2476-2482.

(26) Monteiro, M. R.; Ambrozin, A. R. P.; Lião, L. M.; Ferreira, A. G. Talanta 2008, 77, 593-605.

(27) Knothe, G. J. Am. Oil Chem. Soc. 2006, 83, 823-833.

(28) Liquid petroleum products. Determination of fatty acid methyl esters (FAME) in middle distillates-Infrared spectroscopy method; European Standard EN 14078; 2009.

(29) Edwards, J. C. A Review of Applications of NMR Spectroscopy in the Petroleum Industry. In Spectroscopy Analysis of Petroleum Products and Lubrificants; Nadkarni, R. A. K., Ed.; ASTM International: West Conshohocken, PA, 2011; pp 423-472.

(30) Ovalles, C.; Rechsteiner, Jr., C. E. Analytical Methods in Petroleum Upstream Applications; CRC Press: New York, 2015.

(31) Petrakis, L., Allen, D. NMR for Liquid Fossil Fuels. In Analytical Spectroscopy Library, Elsevier: Amsterdam, 1987.

(32) Freedman, R. JPT, J. Pet. Technol. 2006, 58, 60-66.

(33) Allen, D.; Flaum, C.; Ramakrishnan, T. S.; Bedford, J.; Castelijns, K.; Fairhurst, D.; Gubelin, G.; Heaton, N.; Minh, C. C.; Norville, M. A.; Seim, M. R; Pritchard, T.; Ramamoorthy, R. Oilfield Rev. 2000, 12, 2-19.

(34) Mühl, J.; Srica, V. Fuel 1987, 66, 1146-1149.

(35) Mühl, J.; Srica, V.; Jednacak, M. Fuel 1989, 68, 201-203.

(36) Hiller, W. G.; Abu-Dagga, F.; Al-Tahou, B. J. Prakt. Chem./ Chem.-Ztg. 1992, 334, 691-695.

(37) Meusinger, R.; Schindlbauer, H. GIT Fachz. Lab. 1994, 38, $115-116$.

(38) Meusinger, R. Fuel 1996, 75, 1235-1243.

(39) Meusinger, R.; Moros, R. Fuel 2001, 80, 613-621.

(40) Beebe, K. R.; Kowalski, B. R. Anal. Chem. 1987, 59, 1007A1017A.

(41) Hansen, P. M.; Schjoerring, J. K. Remote Sens. Environ. 2003, 86, $542-553$.

(42) Nguyen, H. T.; Lee, B. W. Eur. J. Agron. 2006, 24, 349-356.

(43) Wold, S.; Trygg, J.; Berglund, A.; Antti, H. Chemom. Intell. Lab. Syst. 2001, 58, 131-150.

(44) Souza, C. R.; Silva, A. H.; Nagata, N.; Ribas, J. L. T.; Simonelli, F.; Barison, A. Energy Fuels 2014, 28, 4958-4962.

(45) Gulder, O. L.; Glavincevski, B. Combust. Flame 1986, 63, 231238.

(46) Basu, B.; Kapur, G. S.; Sarpal, A. S.; Meusinger, R. Energy Fuels 2003, 17, 1570-1575.

(47) Cookson, D. J.; Iliopoulos, P.; Smith, B. E. Fuel 1995, 74, 7078.
(48) Monteiro, M. R.; Ambrozin, A. R. P.; Liao, L. M.; Boffo, E. F.; Tavares, L. A.; Ferreira, M. M. C.; Ferreira, A. G. Energy Fuels 2009, 23, 272-279.

(49) Monteiro, M. R.; Ambrozin, A. R. P.; Liao, L. M.; Ferreira, A. G. Fuel 2009, 88, 691-696.

(50) Monteiro, M. R.; Ambrozin, A. R. P.; Liao, L. M.; Boffo, E. F.; Pereira-Filho, E. R.; Ferreira, A. G. J. Am. Oil Chem. Soc. 2009, 86, $581-585$.

(51) Monteiro, M. R.; Ambrozin, A. R. P.; da Silva Santos, M.; Boffo, E. F.; Pereira-Filho, E. R.; Lião, L. M.; Ferreira, A. G. Talanta 2009, 78, 660-664.

(52) Flores, I. S.; Godinho, M. S.; de Oliveira, A. E.; Alcantara, G. B.; Monteiro, M. R.; Menezes, S. M. C.; Lião, L. M. Fuel 2012, 99, 40-44.

(53) Ferreira, A. G.; Lião, L. M.; Monteiro, M. R. Biofuels. In NMR Spectroscopy: A Versatile Tool for Environmental Research; Simpson, M. J.; Simpson, A. J., Eds.; John Wiley \& Sons: Chichester, U.K., 2014; pp 257-272.

(54) Hills, B. P. Annu. Rep. NMR Spectrosc. 2006, 58, 177-230.

(55) van Duynhoven, J.; Voda, A.; Witek, M.; Van As, H. Annu. Rep. NMR Spectrosc. 2010, 69, 145-197.

(56) Cornejo, F.; Chinachoti, P. NMR in Foods: Opportunity and Challenges. In Magnetic Resonance in Food Science Latest Developments; Belton, P. S., Gil, A. M., Webb, G. A., Rutledge, D., Eds.; The Royal Society of Chemistry, Cambridge, U.K., 2003; pp 25-37.

(57) de Andrade, F. D.; Colnago, L. A. Quim. Nova 2012, 35, 20192024.

(58) Conway, T. F.; Earle, F. R. J. Am. Oil Chem. Soc. 1963, 40, 265268.

(59) Colnago, L. A.; Engelsberg, M.; Souza, A. A.; Barbosa, L. L. Anal. Chem. 2007, 79, 1271-1274.

(60) Pereira, F. M. V.; de Sousa Carvalho, A.; Cabeça, L. F.; Colnago, L. A. Microchem. J. 2013, 108, 14-17.

(61) Carr, H. Y.; Purcell, E. M. Phys. Rev. 1954, 94, 630-638.

(62) Meiboom, S.; Gill, D. Rev. Sci. Instrum. 1966, 29, 93-102.

(63) Hürlimann, M. D.; Venkataramanan, L. J. Magn. Reson. 2002, $157,31-42$.

(64) Goelman, G.; Prammer, M. G. J. Magn. Reson., Ser. A 1995, 113, $11-18$.

(65) Zhang, G. Q.; Hirasaki, G. J. J. Magn. Reson. 2003, 163, 81-91.

(66) Barbosa, L. L.; Kock, F. V. C.; Silva, R. C.; Freitas, J. C. C.; Lacerda, V., Jr.; Castro, E. V. R. Energy Fuels 2013, 27, 673-679.

(67) Silva, R. C.; Carneiro, G. F.; Barbosa, L. L.; Lacerda, V., Jr.; Freitas, J. C. C.; Castro, E. V. R. Magn. Reson. Chem. 2012, 50, 85-88.

(68) Santos, P. M.; Amais, R. S.; Colnago, L. A.; Rinnan, A.; Monteiro, M. R. Energy Fuels 2015, 29, 2299-2303.

(69) AOCS Official Method Ak 4-95, Simultaneous Determination of Oil and Moisture Contents of Oilseeds Using Pulsed NMR Spectroscopy; AOCS: Urbana, IL, 1995.

(70) Prestes, R. A.; Colnago, L. A.; Forato, L. A.; Vizzotto, L.; Novotny, E. H.; Carrilho, E. Anal. Chim. Acta 2007, 596, 325-329.

(71) ABNT NBR 15568. Biodiesel-Determination of Biodiesel Content in Diesel Fuel Oil by Mid Infrared Spectroscopy; ABNT: São Paulo, Brazil, 2008.

(72) Borgia, G. C.; Brown, R. J. S.; Fantazzini, P. J. Magn. Reson. 1998, 132, 65-77.

(73) Pereira, F. M. V.; Colnago, L. A. Food Anal. Methods 2012, 5, 1349-1353. 